\title{
The presence of cytotoxic proteins in females of subfamily Arctiinae moths
}

\author{
By Kotaro Koyama, ${ }^{*)}$ Masahiko Watanabe, ${ }^{*)}$ Toshitami Komatsu, ${ }^{* *)}$ Takashi Sugimura, M. J. A., ${ }^{*)}$ \\ and Keiji WAKABAYASH ${ }^{*}$ \\ (Contributed by Takashi Sugrmura, M.J. A., Nov. 12, 200i)
}

\begin{abstract}
Cytotoxic activity of aqueous extracts from adult moth abdomens of 12 species belonging to the subfamily Arctiinae was tested in vitro using human gastric carcinoma TMK-1 cells. The strong cytotoxic activity, down to a dilution of $1 / 10^{5}$, was found in females of all of 12 species of moths. However, samples of the males of the same species were without cytotoxicity. Females of three species, not of this subfamily, and those of 9 species, belonging to other family than Arctiidae, did not show any cytotoxicity. The strong cytotoxic activity in female abdomens of Hyphantria cunea was located in the ovaries. The active principle in the extract sample from $H$. cunea was inactivated by heat, acid or alkaline treatment and digested by proteases, indicating probably protein in its nature. Thus, cytotoxic factors in moths of the subfamily Arctiinae were likely to be derived from their ovaries.
\end{abstract}

Key words: Cytotoxicity; female; ovary; Arctiinae; Hyphantria cunea.

Introduction. We have previously reported the presence of cytotoxic proteins in some species of butterfly. They were from pupae of cabbage butterflies, Pieris rapae, Pieris brassicae and Pieris napi. ${ }^{1,2)}$ The protein, sized about $100 \mathrm{kDa}$, was purified, characterized and was named as pierisin. ${ }^{3), 4)}$ The entire nucleotide sequences were determined for pierisin-1 and pierisin-2, from $P$. rapae and $P$. brassicae, respectively, ${ }^{5), 6)}$ and their in vitro synthesis was successfully accomplished using a reticulocyte lysate system. They caused apoptosis of cultured human cancer cell lines, such as cervical carcinoma HeLa cells and gastric carcinoma TMK-1 cells. The N-terminal region of pierisin-1 possesses ADP-ribosylating potential, ${ }^{5)}$ surprisingly causing ADPribosylation of $2^{\prime}$-deoxyguanosine residues in DNA. ${ }^{7)}$ The C-terminal region likely possesses ligand functions for cell surface receptors. 5),8)

In attempts to identify other cytotoxic factors, we have expanded search for anticancer substances in moths. Samples of 12 species of the subfamily Arctiinae adult moths including males and females, listed in Table I, were obtained on a white cloth screen illuminated by light at night in July at the Nanae-toge Pass in

\footnotetext{
*) Cancer Prevention Division, National Cancer Center Research Institute, 5-1-1, Tsukiji, Chuo-ku, Tokyo 104-0045, Japan.

**) Hokkaido Goryokaku School for the Handicapped, 39-13, Goryokaku-cho, Hakodate, Hokkaido 040-0001, Japan.
}

Hokkaido or from the National Institute of Agrobiological Sciences. They were stored at $-20{ }^{\circ} \mathrm{C}$ until use in the experiments. Extraction of moth abdomens was carried out with nine volumes of Dulbecco's phosphate-buffered saline (PBS) to make one-tenth diluted solutions, followed by centrifugation and filtration, as previously described. ${ }^{1)}$ Cytotoxic activity of the extract to human gastric carcinoma TMK-1 cells was examined by the method described previously, ${ }^{1)}$ using RPMI-1640 medium supplemented with $10 \%$ fetal bovine serum (Hyclone).

Females of all of 12 species belonging to the subfamily Arctiinae, showed cytotoxic activity to TMK-1 cells at the dilution of $1 / 10^{5}$. However, samples of the males of the same species were without cytotoxicity. In addition, female Hyphantria cunea, either collected in the Southern Japan Alps in Yamanashi prefecture or in downtown Tokyo, showed similar activity, to those from the National Institute of Agrobiological Sciences. As shown in Fig. 1, the extract sample from female abdomens of $H$. cunea exhibited cytotoxicity to TMK-1 cells in a dose-dependent manner, with an $\mathrm{IC}_{50}$ value at the dilution of $1 / 10^{5}$. Moreover, most cytotoxic activity was found to be recovered in the extract samples from the ovaries. The exertion of cytotoxic activity to the cells was rapid, with less than 30 minutes sufficient for morphological changes to become apparent. No apoptotic bodies were observed, but cells became swollen, 
Table I. Cytotoxicity of extracts from subfamily Arctiinae moths

\begin{tabular}{llr}
\hline \multicolumn{1}{c}{ Species $^{\mathrm{a})}$} & \multicolumn{2}{c}{ Cytotoxicity $^{\mathrm{b})}$} \\
\hline Arctia caja & $\mathrm{F}(+)$ & $\mathrm{M}(-)$ \\
Hyphantria cunea & $\mathrm{F}(+)$ & $\mathrm{M}(-)$ \\
Rhyparioides amurensis & $\mathrm{F}(+)$ & $\mathrm{M}(-)$ \\
Rhyparioides nebulosus & $\mathrm{F}(+)$ & $\mathrm{M}(-)$ \\
Spilarctia bifasciata & $\mathrm{F}(+)$ & $\mathrm{M}(-)$ \\
Spilarctia imparilis & $\mathrm{F}(+)$ & $\mathrm{M}(-)$ \\
Spilarctia infernalis & $\mathrm{F}(+)$ & $\mathrm{M}(-)$ \\
Spilarctia obliquizonata & $\mathrm{F}(+)$ & $\mathrm{M}(-)$ \\
Spilarctia seriatopunctata & $\mathrm{F}(+)$ & $\mathrm{M}(-)$ \\
Spilosoma lubricipeda & $\mathrm{F}(+)$ & $\mathrm{M}(-)$ \\
Spilosoma nivea & $\mathrm{F}(+)$ & $\mathrm{M}(-)$ \\
Spilosoma punctaria & $\mathrm{F}(+)$ & $\mathrm{M}(-)$ \\
\hline
\end{tabular}

${ }^{\text {a) }}$ All the samples of moths except for $H$. cunea were obtained in Hokkaido. Female and male of $H$. cunea were from the National Institute of Agrobiological Sciences. ${ }^{\text {b) }}$ Cytotoxicity of each extract of samples of moths was assessed by WST-1 cell proliferation assay using TMK-1 cells. "(+)" indicates detection of cytotoxicity in the extracts from female samples at a concentration of $1 / 10^{5}$ dilution. "(-)" indicates the absence of cytotoxicity in the extracts from male samples at dilution of $1 / 10^{2}-1 / 10^{3}$. F, female; M, male.

assuming the form of necrotic change (Fig. 2).

On the other hand, the species Lithosia quadra, Miltochrista calamina and Pelosia sp., which belong to the family Arctiidae but not to the subfamily Arctiinae, did not exhibit the cytotoxicity even in the females. Moreover, 9 species of female moths, Boarmia roboraria, Gelasma illiturata, Geometra papilionaria, Arctornis L-nigrum, Dasychira abietis, Pida niphonis, Amphipyra schrenckii, Peridea lativitta and Acherontia styx, which belong to other family than Arctiidae, did not show cytotoxicity. Thus, it is concluded that cytotoxic substances are specifically present in the females of the subfamily Arctiinae.

To understand the nature of the cytotoxic substance(s) in the abdomen of female $H$. cunea, the extract sample was subjected to various treatments by the method described previously ${ }^{1)}$ and its cytotoxicity to TMK-1 cells was assessed. Cytotoxic activity almost disappeared after $1 \mathrm{~h}$ incubation at $60{ }^{\circ} \mathrm{C}$, while the original activity remained at $40{ }^{\circ} \mathrm{C}$ or lower. Most cytotoxic activity could be recovered by addition of ammonium sulfate powder to give $80 \%$ saturation. On the other hand, cytotoxic substances were not extracted with organic solvents such as chloroform. Strong acid $(\mathrm{pH} 1)$ or alkaline ( $\mathrm{pH} 13)$ treatment of the sample for $1 \mathrm{~h}$ at 37 ${ }^{\circ} \mathrm{C}$ caused complete loss of the activity. Exposure to $\mathrm{pH} 3$ or $\mathrm{pH} 11$ for $1 \mathrm{~h}$ at $37{ }^{\circ} \mathrm{C}$ caused one-third loss of the

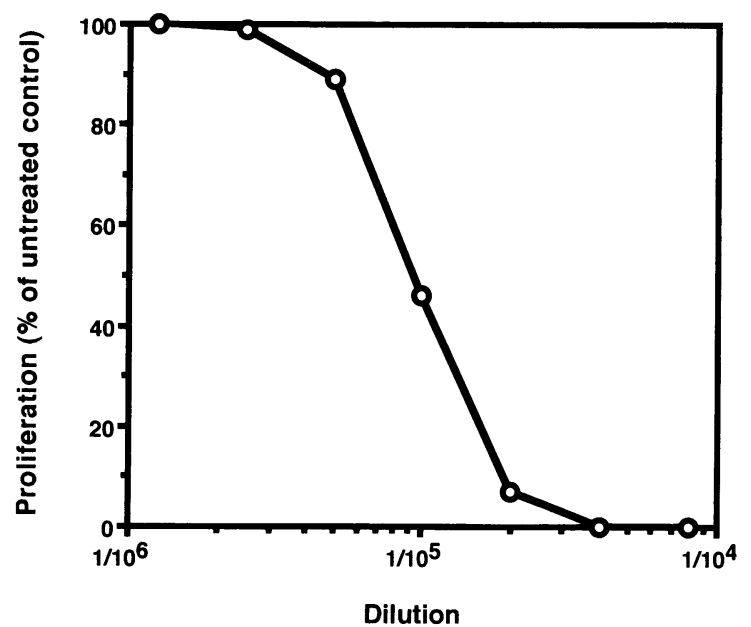

Fig. 1. Dose-dependent cytotoxic effect of the extract from female abdomens of $H$. cunea on TMK-1 cells. Sample at various dilutions was incubated with TMK-1 cells for $48 \mathrm{~h}$ and subjected to WST-1 cell proliferation assay.

cytotoxicity. In a solution of $\mathrm{pH} 5$ to 9 , the activity remain unchanged. Active substance did not pass through microcon 30 (Amicon) while partially or freely passing through microcon 50 or 100, respectively. This suggests a molecular mass of around $30 \mathrm{kDa}$. Enzyme digestion experiments showed both pronase and proteinase $\mathrm{K}$ to cause complete inactivation. However, micrococcal nuclease, spleen phosphodiesterase II and nuclease P1 were without effect. All the properties observed are consistent with that the active substance found in $H$. cunea to be protein.

In the present study, we demonstrated the presence of cytotoxic factors in female moths specifically those belonging to the subfamily Arctiinae. Moreover, cytotoxicity was found in the ovary of $H$. cunea, and the active principle was suggested to be protein. Therefore, it is conceivable that the source of cytotoxicity in female moths of the other species is also to be found in their ovaries. Eggs might contain bio-active materials, such as the well known enzyme, lysozyme, which exerts bactericidal effects. Eggs also contain substances which are responsible for conducting oogenesis and embryogenesis, which might show cytocidal effects. It has been reported that the female of an Arctiid moth, Arctia caja, contains proteinaceous toxin in its abdomen. ${ }^{9)}$ This substance was shown to be toxic to both house flies and mice when injected, however, the toxic protein has not been characterized yet. The cytotoxic protein found in the present study may play some role as an agent protecting eggs from predators or invading organisms. However, the 
A

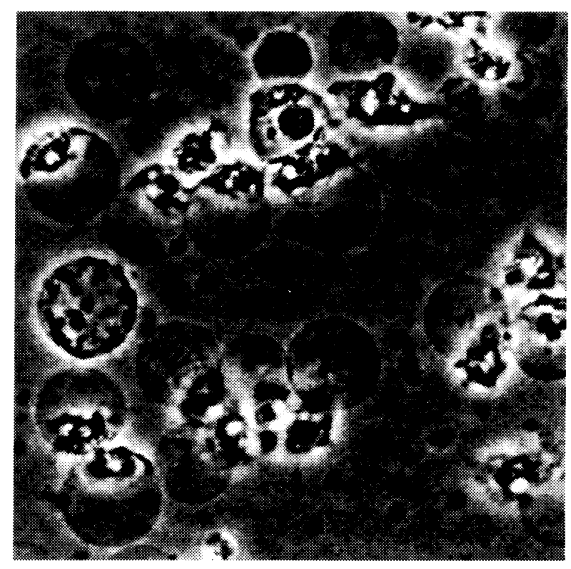

B

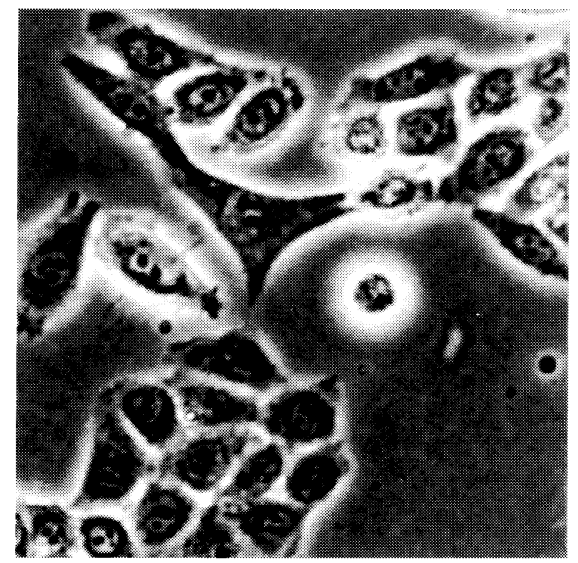

Fig. 2. Phase-contrast micrographs of TMK-1 cells treated with or without an extract from female abdomens of $H$. cunea. (A) The cells were incubated with medium containing the extract at a concentration equivalent to $1 / 10^{4}$ of original body fluid, for $3 \mathrm{~h}$. (B) The cells were incubated without the extract.

reason why it is specifically present in female moths belonging to Arctiinae remains to be elucidated. This is also interesting in phylogenetic point of view. Exploration of its biological significance is clearly warranted, and isolation and identification of the cytotoxic protein in the ovary of $H$. cunea is now under investigation in this laboratory.

Acknowledgments. This study was supported by a Grant-in-Aid for Cancer Research from the Ministry of Health, Labor and Welfare.

\section{References}

1) Koyama, K., Wakabayashi, K., Masutani, M., Koiwai, K., Watanabe, M., Yamazaki, S., Kono, T., Miki, K., and Sugimura, T. (1996) Jpn. J. Cancer Res. 87, 1259-1262.

2) Kono, T., Watanabe, M., Koyama, K., Sugimura, T., and Wakabayashi, K. (1997) Proc. Japan Acad. 73B, 192-194.

3) Watanabe, M., Kono, T., Koyama, K., Sugimura, T., and Wakabayashi, K. (1998) Jpn. J. Cancer Res. 89, 556-561.
4) Kono, T., Watanabe, M., Koyama, K., Kishimoto, T., Fukushima, S., Sugimura, T., and Wakabayashi, K. (1999) Cancer Lett. 137, 75-81.

5) Watanabe, M., Kono, T., Matsushima-Hibiya, Y., Kanazawa, T., Nishisaka, N., Kishimoto, T., Koyama, K., Sugimura, T., and Wakabayashi, K. (1999) Proc. Natl. Acad. Sci. U.S.A. 96 10608-10613.

6) Matsushima-Hibiya, Y., Watanabe, M., Kono, T., Kanazawa, T., Koyama, K., Sugimura, T., and Wakabayashi, K. (2000) Eur. J. Biochem. 267, 5742-5750.

7) Takamura-Enya, T., Watanabe, M., Totsuka, Y., Kanazawa, T., Matsushima-Hibiya, Y., Koyama, K., Sugimura, T., and Wakabayashi, K. (2001) Proc. Natl. Acad. Sci. U.S.A. 98 12414-12419.

8) Kanazawa, T., Watanabe, M., Matsushima-Hibiya, Y., Kono, T., Tanaka, N., Koyama, K., Sugimura, T., and Wakabayashi, K. (2001) Proc. Natl. Acad. Sci. U.S.A. 98, 2226-2231.

9) Hsiao, T. H., Hsiao, C., and Rothschild, M. (1980) Toxicon 18 , 291-299. 